\title{
Sombras e luzes: reprodução técnica, os rastros efêmeros do desaparecimento e o "puro traço" na obra de Regina Silveira
}

Márcio Seligmann-Silva UNICAMP

Resumo: O texto explora a poética de sombras e luzes na obra da artista plástica Regina Silveira, apresentando seus vínculos com a antiga tradição da skiagraphia e com a história do pensamento e da reflexão sobre a sombra. $O$ trabalho mostra como a sua escrita de sombras, que remetia a algo recalcado e ausente, metamorfoseia-se em uma escrita de luz, "puro traço" sem anguistia da ausência.

Palavras-chave: skiagraphia, sombra, escrita de luz.

Efêmeros! O que é alguém? O que não é alguém? Sonho de uma sombra: o bomem. Mas quando o brilbo do dote divino vem, a luz radiante sobrepaira nos bomens e a vida se torna doce como mel.

Pindaro, Oitava Pítica, 94-97 (tradução: Humberto Zanardo Petrelli) 
Entre outubro de 2009 e janeiro de 2010, aconteceu, no Centro Cultural Banco do Brasil do Rio de Janeiro, uma exposição de Regina Silveira, intitulada "linha de sombra", que tinha como proposta repensar a trajetória da artista a partir de certos conceitos. Os dois termos desse título podem ser vistos também como parte da cartografia imagético-conceitual que os curadores, José Roca e Alejandro Martin, procuraram traçar então. O belo catálogo - todo em preto e branco - abre-se com dois verbetes de dicionário: "luz" e "sombra". A exposição e o catálogo seguem a enumeração destes e de outros conceitos, tais como anamorfose, arquitetura, ausência, desaparências, dobras, eclipses, ironia, labirinto, meios, paradoxo, perspectiva, poesia, política, quimera, rastros, simulacro, tensões, entre outros. Aqui, já surpreendemos um gosto por arquivamentos e taxonomias absurdas que ecoam da "obra arquivo" de outro pensador e criador de imagens do século XX, a saber, Walter Benjamin, autor do work in progress Trabalho das Passagens. Vale a pena recordar algumas passagem das definições iniciais de luz e de sombra do catálogo de Silveira. No verbete Luz lemos:

luz (Do lat. lux, lucis). Agente físico que torna visíveis os objetos [...] Esclarecimento ou clareza de inteligência. II f. Modelo, pessoa ou coisa, capaz de ilustrar e guiar. I I f. dia (tempo em que o Sol está no horizonte) [...] f. Pint. Ponto ou foco de onde é iluminada a história e os objetos pintados numa tela [...] f. pl. Ilustração, cultura. O século das luzes. Homem de muitas luzes. I I luz da razão. F. Conhecimento que temos das coisas pelo natural discurso que nos distingue dos animais irracionais [...] I । luz primária. F. Pint. A que provém diretamente do corpo luminoso. I I luz refletida, ou luz secundária. F. Pint. A que provém de objeto iluminado pela luz primária [...] dar à luz. Loc. verb. Dito de uma mulher. parir. II loc. verb. Publicar uma obra. ${ }^{1}$

E no verbete sombra, entre outras coisas, lemos:

Sombra s.f. A falta de luz causada por opposição [sic] de corpo que não dá passagem aos raios [...] Na pintura, a parte dela que fica depois dos altos, onde a luz fere, os quaes [sic] se representa que tomão $[s i c]$ a luz às sombras [...] As sombras do sepulcro, do Inferno; i. é, as trevas "já a sombra da morte me cobre" [...] O que sempre acompanha a outro se diz sua sombra. ${ }^{2}$

1. SILVEIRA. Linha de sombra, p. 1.

2. SILVEIRA. Linha de sombra, p. 2. 
Na apresentação do mesmo catálogo, feita pelos curadores, um dos temas centrais é o do rastro. Pensando o conceito da exposição, calcada em certas palavras/conceitos eles escrevem: "A definição de uma palavra sempre tem vestígios das que a antecedem: cada palavra é a sombra de muitas outras." ${ }^{3}$ Ou seja, podemos pensar que cada palavra-luz (ou palavra-arquivo), traz suas sombras e, por sua vez, projeta sombras sobre outras palavras. O termo no qual os curadores encontram mais nuances é justamente "sombra", definida como "claridade atenuada; sinal ou marca; fantasma ou espectro; abajur, rastro ou vestígio; sonho ou aparência; ideia vaga ou noção sutilmente insinuada de algo; segredo, mistério." ${ }^{4}$ Do conceito de sombra, eles desdobram o de vestígio e rastro, para chegar ao de índice, categoria peirceana central na obra de Regina Silveira, como ela mesma o reconhece, em diversas ocasiões. Não esqueçamos: estamos lidando com uma artista da tradição do pictor doctus. O índice implica uma relação real, de proximidade e pertença espacial, ocorrida em algum momento entre o objeto e seu índice. Podemos dizer que a obra de Regina Silveira em boa parte é uma pesquisa em torno do índice, que ela trabalha sob a forma da luz, da sombra, dos rastros e dos traços.

Regina Silveira estudou gravura nos anos 1960 e, nos anos 1970, coordenou uma oficina de gravura na Universidad de Puerto Rico. Ali fez suas primeiras serigrafias, e estudando a fotomecânica, expandiu as fronteiras da gravura. Como ela nos conta em uma entrevista: "Da serigrafia transitei para a litografia com recursos fotográficos, e dela para o offset, a fotocópia, o blueprint, a microfilmagem, o vídeo, enfim, entrei no mundo amplo da gráfica 'outra', desartistificada, que era a 'moeda de troca' daqueles anos..." Regina Silveira, ao construir suas obras, sobretudo a partir de início dos anos 1980, como verdadeiras escrituras de sombra - revertendo mas em diálogo com o paradigma da foto-grafia - mergulhou em um projeto que não só retoma a história da representação para repensá-la, como também reverbera e dá forma ao abalo profundo da representação na modernidade, radicalizado na era da reprodutibilidade fotográfica e com maior razão nos dias de hoje, dominados pela era digital. Pretendo mostrar alguns aspectos desse projeto e para tanto a obra de Walter Benjamin e algumas de suas imagens serão de grande proveito. Afinal, Benjamin fez parte das vanguardas históricas da

3. SILVEIRA. Linha de sombra, p. 8.

4. SILVEIRA. Linha de sombra, p. 8.

5. Entrevista cedida pela artista. 
primeira metade do século XX, e foi naquele contexto, sobretudo com o cubismo, o dada e o suprematismo, que esse tipo de projeto artístico se explicitou.

A artista se coloca numa longuíssima tradição das artes e da reflexão sobre a visão e as imagens, ao centralizar sua obra na skiagraphia e depois, sobretudo a partir dos anos 2000, na escrita com a própria luz. Este apego à autoreflexão e ao metadiscurso não deixa de transmitir sua proximidade com o concretismo paulista, durante os anos de sua formação. Lembremos que Haroldo de Campos era um admirador de sua obra e que Júlio Plaza foi seu marido. Assim, proponho que reflitamos sobre o conceito de skiagraphia e sobre o sentido de retomar este princípio hoje. Lumen et umbrae são os termos latinos que traduziam o grego skiagraphia, literalmente, escrita com a sombra. Apolodorus, o pintor grego que viveu no final do século V a. C., era conhecido como skiagráphos. Plínio, o velho, identificava Apolodoro como um dos pais da pintura e também a própria expressão lumen et umbrae era para ele sinônimo da pintura (para diferenciá-la do desenho). ${ }^{6}$ Não caberia entrar aqui em detalhes sobre o significado exato do termo grego skiagraphia, mas é importante lembrar que ele foi entendido tanto como uma tentativa de se criar a ilusão da cor pela utilização do sombreado, como também de se buscar introduzir a perspectiva na pintura. Os especialistas disputam se a tradução correta seria chiaroscuro, sombreamento ou mesmo perspectiva. Ao longo da história, devido a uma proximidade fônica, a skiagraphia foi aproximada também da skenographia, ou seja, da pintura de cena. Todos estes caminhos interpretativos e tradutórios são, como é evidente, ricos em significado. Estes traços e vestígios de sentido vão dando tons diversos ao termo skiagraphia e esta riqueza é explorada pela obra de Regina Silveira.

Seguindo uma intuição de Victor Stoichita, autor de uma bela obra Breve história da sombra (obra aliás, citada por Regina Silveira em entrevistas), podemos pensar que existe algo como um paradigma da sombra na história ocidental, que pode ser contraposto ao paradigma mais solar e luminoso do reflexo. Neste conflito, poderíamos imaginar que, do mesmo modo que Derrida (no contexto das neovanguardas dos anos 1960) detectou um recalcamento da escritura na história do logos ocidental, seria possível conceber também um recalcamento da sombra. Para Derrida, o $\log o s /$ fala preponderou sobre a escritura, reservando a esta última um papel secundário, derivado, da primeira. Pensando na luta entre as imagens

6. KEULS. Plato and the Greek Painting, p. 72 e seguintes.

7. STOICHITA. Breve histoire de l'ombre. 
luminosas e as escuras, vale lembrar que, do mesmo modo, no mundo mitológico clássico, a Noite, mãe das Fúrias, é submetida à linhagem de Zeus e Apolo, masculina e solar. Como vimos na definição do dicionário citada, da luz se diz "O século das luzes. Homem de muitas luzes." Enquanto que a mulher dá à luz, pare filhos. Se a "luz da razão" é definida como o que "nos distingue dos animais irracionais", o dar à luz das mulheres ainda estaria no âmbito "animal". Já a sombra é o "outro", um duplo, o que acompanha o próprio, mas não é um si mesmo.

Para entrar na cena da obra de Silveira, é importante antes recordar dois mitos fundamentais dentro da história da skiagraphia, que Stoichita no seu mencionado ensaio também não pôde deixar de lado. Um é o mito da caverna platônico, o outro é o mito da origem da pintura, narrado por Plínio e por Quintiliano, entre outros. O exemplo da caverna é tanto mais importante no nosso contexto, porque ele parte de uma crítica da percepção e de um elogio da inteligência e do conhecimento intelectual. Regina Silveira, na contramão desta posição, defende uma exploração da percepção e sua transformação pelas artes. Mas, o dispositivo da caverna em si é digno de nota, sobretudo porque é carregado de ambiguidades, como costuma acontecer com o pensamento de Platão. Nele, encontramos a humanidade amarrada diante de um espetáculo de sombras. Lembremos a famosa passagem do diálogo de Sócrates e Glauco:

[Sócrates:] Em seguida [...] compara o efeito da educação e da sua falta na nossa natureza a uma experiência como a seguinte: imagina seres humanos habitando uma espécie de caverna subterrânea, com uma longa entrada acima aberta para a luz e tão larga como a própria caverna. Estão ali desde a infância, fixados no mesmo lugar, com pescoços e pernas sob grilhões, unicamente capazes de ver à frente, visto que seus grilhões os impedem de virar suas cabeças. Imagina também a luz de uma fogueira acesa a certa distância, acima e atrás deles. Também atrás deles, porém num terreno mais elevado, há uma vereda que se estende entre eles e a fogueira. Imagina que foi construído ao longo dessa vereda um muro baixo, como o anteparo diante de manipuladores de marionetes acima do qual eles os exibem.

[Gláucon:] - Eu o estou imaginando.

[Sócrates:] - Então também imagina que há pessoas ao longo do muro, carregando todo tipo de artefatos que são erguidos acima do nível do muro: estátuas de seres humanos e de outros animais, feitas de pedra, madeira e todo material. E, como seria de esperar, alguns desses carregadores conversam, ao passo que outros estão calados. 
[Gláucon:] - Descreves uma imagem estranha [...] e prisioneiros estranhos.

[Sócrates:] - São como nós. Supões, em primeiro lugar, que esses prisioneiros veem alguma coisa de si mesmos e uns dos outros além das sombras que a fogueira projeta sobre o muro à frente deles?

[Gláucon:] - E como poderiam, se têm de manter suas cabeças imóveis através da vida?

[Sócrates:] - E quanto às coisas que são carregadas ao longo do muro? O mesmo se aplica a elas?

[Gláucon:] - Claro.

[Sócrates:] - E se eles pudessem falar entre si, não achas que suporiam que ao nomear as coisas que vissem estariam nomeando as coisas que passam diante de seus olhos?

[Gláucon:] - É o que suporiam.

[Sócrates:] - E se se sua prisão produzisse um eco que viesse do muro que se opõe a eles? Não achas que acreditariam que as sombras que passam diante deles estivessem falando toda vez que um dos carregadores que caminhasse ao longo do muro o estivesse fazendo?

[Gláucon:] - Certamente acho.

[Sócrates:] - Por conseguinte, os prisioneiros acreditariam cabalmente que a verdade não seria nada mais senão as sombras desses artefatos.

[Gláucon:] - Isso necessariamente.

Mais adiante, Sócrates arremata: "Toda essa imagem, Gláucon, deve ser aplicada ao que dissemos anteriormente. A região visível deveria ser comparada à morada, que é a prisão e a luz da fogueira nela ao poder do sol. E se interpretares a subida e o exame das coisas acima como a ascensão da alma à região inteligível, terás captado o que espero transmitir, uma vez que isso é o que querias ouvir. Se isso é verdadeiro ou não, só o deus o sabe." Como nota Stoichita, ${ }^{10}$ se nesta passagem as sombras são tratadas como phantasmata, em outra, da República, pouco anterior a esta imagem (alegoria ou mito) da caverna, Platão havia feito

8. Platão. A república. (Da justiça), 514a-515c; p. 307s.

9. Platão. A república. (Da justiça), 517b; p. 310.

10. STOICHITA. Breve histoire de l'ombre, p. 25. 
uma distinção do visível "segundo o grau de clareza e de obscuridade" afirmando: "Por imagens (eikona) entendo em primeiro lugar, sombras (skias), em seguida reflexos na água (phantasmata) em todas as superfícies de textura densa, lisa e reluzente, e tudo desse gênero, se é que entendes." Ainda segundo Stoichita, para Platão, são as sombras o "estágio mais distante com relação à verdade". ${ }^{12} \mathrm{Na}$ teoria das artes como mímesis, onde aparecem como cópias de cópias, na mesma República, podemos ver uma condenação da skiagraphia que, segundo Stoichita, vale tanto para seu sentido de pintura de sombras, um simulacro, como também para sua acepção como perspectiva, ou seja, ilusão mimética. Platão escreve: "é porque exploram essa debilidade de nossa natureza (pathêma) que a pintura enganosa [de sombras] (skiagraphia), a feitiçaria (thaumatopoia) e outras formas de prestidigitação têm poderes aos quais pouco falta de magia (goêteia)." ${ }^{13}$

Essa trama platônica que tenta criar via "mito" uma origem solar para a verdade e hierarquizar as imagens, não deixa de ser perturbadora em sua autoironia da qual nunca conseguiremos nos libertar inteiramente. Ademais, se estamos na caverna, não poderíamos ver sua estrutura. Se a vemos - como no mito, é porque um dispositivo escópico sobre o funcionamento da visão foi criado por Platão - e, por outro lado, se nos pomos a questionar Platão por seu logocentrismo, caímos na armadilha de depreciar sua imagem como mero mito, alegoria ou qualquer outra ofensa que implicaria seu menor valor. O mito mesmo é um teatro de imagens e Sócrates se preocupa em deixar sua encenação bem clara a Glauco, representante dos espectadores/leitores, nessa passagem citada do diálogo... Ao criticar Platão e condenar essa encenação como mero mito tornamo-nos, nós mesmos, de certo modo, também "platônicos". Esta astúcia faz parte do platonismo e de seu dialogismo dialético. O mais importante, portanto, é a estrutura da cena da caverna ou do teatro de representação e da mímesis. Já quanto ao dispositivo da projeção, nele a sombra tem um papel fundamental ao lado dos reflexos, centrais na crítica das representações artísticas. Passemos rapidamente a Plínio.

Citemos as duas passagens tópicas da História natural, escritas por este autor, no primeiro século:

11. PLATÃO. A república. (Da justiça), 509d a 510a.

12. STOICHITA. Breve histoire de l'ombre, p. 25.

13. Platão. A república. (Da justiça), 602d. 
A questão das origens da pintura é obscura [!] [...] Os egípcios afirmam que esta arte foi inventada por eles, seis mil anos antes de passar à Grécia; isto é manifestação de uma vã pretensão. Entre os gregos uns dizem que ela foi descoberta em Sicyone, outros, em Corinto, mas todos afirmam como iniciou-se por riscar com um traço o contorno da sombra humana (omnes umbra hominis lineis circunducta). Este foi o primeiro método; o segundo, utilizando cores isoladas, foi o chamado monocromo: em seguida vieram os aperfeiçoamentos, mas ele ainda existe. ${ }^{14}$

Mais adiante, Plínio narra o "mito" de origem da escultura e, mais uma vez, a origem é criada a partir de um teatro de sombras.

Já dizemos mais do que o necessário sobre a pintura. Seria indicado acrescentar a essas observações algo sobre as esculturas [...] modelando retratos a partir da argila foi primeiro inventada por Dibutades [ou Butades], um oleiro de Sicyon, em Corinto. Ele fez isso graças à sua filha, que estava apaixonada por um jovem; ela, quando ele estava partindo, desenhou contornando na parede a sombra de sua face projetada por uma lamparina. Seu pai calcou argila sobre isso e fez um relevo, que endureceu expondoo ao fogo com o resto de seus trabalhos; e diz-se que o tipo foi preservado no templo das Ninfas em Corinto até a sua destruição por Mummius. ${ }^{15}$

Esta origem da escultura retoma a ideia da origem da pintura: ambas se devem a um decalque da sombra e são imagem de uma imagem, como em Platão. Mas, este mito acrescenta à ideia platônica da caverna um elemento importante: há um ente amado que parte, e, o traçamento de sua sombra, por sua amada, bem como a construção da estátua, por seu pai, surgem como uma espécie de substituto daquele que se foi, objetivando aplacar a saudade. A arte nasce como consolo, como contraparte da morte e do desaparecimento. Ela é altamente erotizada nessa passagem, mas também transformada em culto, pois, afinal, a estátua acaba no templo das Ninfas, em Corinto. Esse mito recorda também a relação entre sombra e morte, conforme já vimos na citada definição do dicionário, o que se revelava uma constante na cultura clássica. Stoichita, ${ }^{16}$ no entanto, defende

14. PLINIO apud STOICHITA. Breve histoire de l'ombre, p. 11.

15. PLINIO. História natural, XXXV, 43.

16. STOICHITA. Breve histoire de l'ombre, p. 37. 
a tese de que esta origem skiagraphica da pintura será recalcada a favor de um modelo do amor pelo si mesmo. Ao invés da imagem da sombra como outro, predominará, a partir do Renascimento, a noção da arte como autorretrato: contorno narcisista do artista. Apenas com o abalo do modelo clássico, a partir do século XVIII, que as sombras teriam iniciado sua volta na nossa visão das artes. Acredito que este regresso da sombra deve ser interpretado como paralelo ao nascimento do tipo moderno, composto por uma interioridade complexa que o termo Unheimlich (cunhado por Schelling e adotado por Freud, como imagem para nosso mundo anímico) nos apresenta de modo condensado.

A obra de Regina da Silveira é uma afirmação da skiagraphia em seu sentido forte de retorno do recalcado. Seu trabalho possui algo de uma arqueologia da presença/ausência da sombra nas artes e acaba se desdobrando em uma desconstrução da ideia solar, apolínea, de Luz como origem. Nesse seu projeto artístico, entrecruzam-se três momentos da crítica romântica: ao logocentrismo, à mímese a a classicismo. Para a visão do século XVIII, como lemos em Locke, em seu An Essay Concerning the Human Understanding, a mente humana seria como um quarto escuro iluminado pela entrada do conhecimento. ${ }^{17}$ Ao reverter a hierarquia entre o claro e o escuro, as luzes e as sombras, artistas como Silveira desmontam esse padrão iluminista do saber. Eles desvelam o momento de sombra, ou, com Derrida, o elemento escritural, da cultura. Essa relação intensa da obra de Silveira com as sombras recupera também toda uma vertente romântica que lida com o maravilhoso, com o sublime e o Unheimlich, tradição esta pontuada por escritores como Marry Shelley, Edgar Allan Poe, Baudelaire e Albert von Chamisso (autor da novela Peter Schlemihl wundersame Geschichte, que narra a história de um homem que vendeu sua sombra a um diabrete). Artistas como Henry Fusely (autor de Cauchemar, obra na qual vemos um diabo ensombrecido sobre uma

17. "I pretend not to teach, but to inquire; and therefore cannot but confess here again, - that external and internal sensation are the only passages I can find of knowledge to the understanding. These alone, as far as I can discover, are the windows by which light is let into this dark room. For, methinks, the understanding is not much unlike a closet wholly shut from light, with only some little openings left, to let in external visible resemblances, or ideas of things without: which, would they but stay there, and lie so orderly as to be found upon occasion, it would very much resemble the understanding of a man, in reference to all objects of sight, and the ideas of them." LOCKE. An Essay Concerning the Human Understanding, p. 9. 
pálida mulher desfalecida), Caspar David Friedrich (que foi um dos inventores da paisagem Unheimlich), Goya (quem desenhou o interior da pessoa moderna e os espectros que a assombram), representam esta tradição nas artes plásticas. ${ }^{18}$ Silveira revela a convergência nada evidente entre os jogos maneiristas e barrocos com a perspectiva e a anamorfose e um movimento de ida à tona do Unheimlich.

Ela mesma o afirma: "A meta é o próprio conceito de estranheza, manifesto como paradoxo perceptivo, uma disrupção, uma descontinuidade, ou uma descontextualização." Através de jogos anamórficos e com sombras, a artista aponta para um lado recalcado da cultura, para o Unheimlich de Freud, ou ainda, para aquilo que Derrida, em sua Gramatologia, denominou elemento escritural da cultura. Nos trabalhos de Regina Silveira, o duplo faz parte de uma desconstrução da ideia de Eu como um ser consciente de si e dono de suas ações. Ela em boa parte faz esta desmontagem através da crítica da representação em seu modelo clássico. O indivíduo em conflito com sua sombra é também uma alegoria da situação do indivíduo alienado moderno que possui um "outro" dentro de si. Ele deixa de ser um "indivíduo" e se revela agora, a partir da modernidade, como um "divíduo". O outro dentro dele, é na verdade plural, são seus outros, seus fantasmas, seu inconsciente e seus traumas. Essa situação tem raízes históricas conhecidas.

Não nos esqueçamos que o Schlemihl da história de Chamisso troca sua sombra por um saco mágico que produz indefinidamente dinheiro. Ao colocar a sombra em primeiro plano, esta nova tradição ajudou também a forjar este indivíduo moderno que é marcado pelo mal-estar (Unbehagen), pelo seu inconsciente (Unbewusst), e por uma corporeidade que ao mesmo tempo the seduz e é abjetada. Este também é o indivíduo prometéico, que é condenado por ter roubado a luz e vê na técnica ao mesmo tempo a sua libertação e condenação. Se Deus fez Adão à sua forma e a partir do barro, Dibutades, no mundo clássico, repetiu sua ação com auxílio da astúcia de sua filha. Mas o homem moderno vai tentar refazer este percurso de trás para frente: ele se dirige agora à sombra. Não por acaso no século XVIII temos uma profusão e representações de Dibutades e,

18. Para uma interpretação da história da cultura desde o romantismo como manifestação do sublime (ou o "delicioso horror sublime", tradução do trágico ocorrida no conceito de sublime, na segunda metade do século XVIII) e também do abjeto, remeto o leitor ao meu livro: SELIGMANN-SILVA. O local da diferença. Ensaios sobre memória, arte, literatura e tradução.

19. SILVEIRA. Linha de sombra, p. 20. 
no século XIX, o homem prometéico moderno inventa uma arte de inscrição de luz (a fotografia), que é uma nova skiagraphia e, no final do mesmo século, consegue traduzir em um aparelho eletrônico a cena originária da caverna platônica. Porém, agora esse ser moderno está irremediavelmente apaixonado pela imagem, pela fantasmagoria. As imagens são seu culto, como observamos nas obras de Baudelaire e Benjamin.

Feita esta pequena introdução histórica, tentemos agora nos aproximar das obras de Regina Silveira. Iniciemos com algumas de suas séries Dilatáveis e Simulacros, do início dos anos 1980. Elas desdobram as pesquisas e obras da década anterior, sobretudo as gravuras e desenhos da série Anamorfas, que trabalhavam com a tradição barroca da anamorfose - consagrada por Jean-François Niceron no século XVII - e já estavam fazendo uma autorreflexão irônica sobre a história da representação. Refiro-me às obras de Silveira como In absentia (for Giselda Leirner), de1982 e a In absentia: M.D., de 1983. Na obra dedicada à Giselda Leirner vemos a sombra de um cavalete. Se o cavalete é um tema tradicional na história da pintura e é relacionado à tradição da pintura como autoencenação do artista, que se acentua desde o Renascimento, ao transformar o cavalete na sua sombra, Silveira reverte toda uma tradição.

Como mostrou Stoichita, ${ }^{20}$ Picasso já deslocara a figura do cavalete e do autorretrato do artista para uma área de sombra. Um outro nome chave nessa história é, como Silveira reconhece, Marcel Duchamp. Daí seu In absentia: M.D. conter as iniciais do artista. Aqui, as sombras atuam como citações irônicas. A própria ironia do ready made é reativada e deslocada com este jogo de sombras. Silveira não apenas torna etéreo o objeto "original", mas nos faz pensar tanto na sombra que o gesto de Duchamp lança sobre a história da arte e sobre os artistas que o sucederam, como também indica um novo momento das artes que, na era da revolução midiática, está dirigindo as imagens para o campo do virtual. Talvez, não tanto abrindo este campo, mas o reativando, já que o virtual também foi fundamental na história da arte e teve seu grande momento no barroco, com suas perspectivas em tromp l'oeil. Os pedestais com Bicycle Wheel (1913) e Bottle Rack(1914) estão vazios, só restaram suas sombras. A ausência é transformada em paradoxo, na medida em que Silveira rompe a causalidade indicial imediata e contínua que existe entre a sombra e seu objeto. Se o ready made superava a ideia de cópia da natureza, Silveira, com sua skiagraphia, rompe a relação entre

20. STOICHITA. Breve histoire de l'ombre, p. 119-129. 
sombra e representação. Ela toma do dispositivo da representação do mito de Dibutades apenas a sombra. Não existe mais uma poética da saudade. A ausência torna-se presente contínuo. Ao invés de representação, vemos a apresentação da ausência, temos um jogo de traços, de sombras congeladas e desconectadas dos referentes. A sombra, que na história da skiagraphia servia para acentuar a ilusão da representação, serve agora, pelo contrário, para mostrar a ausência.

Este gesto de Schlemihl, de cortar a sombra de seu "dono", pode ser visto também como uma referência à própria história da arte que passa agora a ser vista como um acúmulo e deslocamento de obras do passado, as quais lançam sua sombra para nosso presente. Aliás, o próprio Duchamp já havia mostrado este potencial, por assim dizer, de arquivo skiagraphico das imagens em sombra. Em 1918, ele realizou o seu Tu m', uma enorme tela, sua última e maior, que cita e arquiva suas obras anteriores: os ready made Bicycle Wheel (1913), Hat Rack (1917) e o ready made apenas planejado saca-rolhas. Todas estas obras aparecem apenas como sombras nessa grande tela. No canto direito, vemos também projeções anamórficas de Standart Stoppages (1913-14). Para copiar seus ready mades, Duchamp atuou como a filha de Dibutades: "Eu tive que encontrar uma espécie de projetor que produzia sombras de modo suficientemente bom e eu projetei cada sombra que eu tracei à mão na tela." ${ }^{21}$ Não por acaso, ao lado da sombra do saca-rolhas (instrumento este, aliás, que também foi anamorfoseado por Silveira em 1979), vemos uma mão com o indicador em riste, evidenciando e ironizando o jogo indicial da obra. Duchamp realizou este trabalho, uma encomenda de sua marchand Katherine Dreier, a contragosto, daí o título sugestivo: Tu m [emmerdes]. Mas, na verdade pôde concretizar com isso um antigo plano de fazer uma imagem usando "sombra[s] com 2.3.4 Readymades" .

Silveira, ao retomar esse gesto de Duchamp, de citar as suas próprias obras, o desloca e o ressignifica. Os pedestais apontam para a entronização ocorrida

21. DUCHAMP apud SCHWARZ. The Complete Works of Marcel Duchamp, p. 658.

22. Duchamp utiliza a sombra e sua poética em outras obras, como no seu Nine Malic Moulds (1914-15, um dos estudos para o The Bride Stripped Bare by Her Bachelors, Even, ou simplesmente seu The Large Glass), em Door for Gradiva (1937, um diálogo com o romance de Wilhelm Jensen que impressionou Freud e os surrealistas, cuja história trata de pegadas, rastros e fantasmas) e, ainda, no seu Self-Portrait in Profile (1958, analisado também por Stoichita no referido ensaio sobre a sombra). DUCHAMP apud SCHWARZ, The Complete Works of Marcel Duchamp, p. 658. 
ao longo do século XX do ready made e de seu autor. Assim, a artista utiliza as sombras não apenas como arquivo, mas as incorpora também a um novo regime escópico da era do virtual. Portanto, as sombras e silhuetas estão na vanguarda de um movimento de emancipação das imagens de sua tutela do(s) original(ais). Se Benjamin notou que com a reprodutibilidade técnica ocorrera um violento abalo na tradição e o testemunho histórico se tornara cada vez menos possível, e se para ele também, a Spurindicava uma presença, por mais distante que esteja, ${ }^{23}$ Silveira transforma o puro traço, a Spur, não em proximidade, ou mesmo em presença de um ausente, como afirmei acima e normalmente se lê na obra dela, mas em simples imagem. Na era digital, não tem mais sentido se falar na diferença entre o objeto e sua sombra. Daí suas silhuetas serem puros traços: não são meios, mas traços que se bastam a si mesmos. Silveira foi uma das primeiras a discutir esta liquefação do real em uma obra que, de modo persistente e sistemático, tem trabalhado com o dispositivo de Dibutades e com seu correlato moderno, o dispositivo fotográfico. De modo aparentemente paradoxal, a fotografia analógica pode ter representado um abalo na noção de tradição justamente porque se apresentava como a possibilidade de arquivamento total. A ideia de arquivamento é gêmea da noção de efemeridade dos traços culturais. Na era da Internet e dos mega arquivos virtuais, este abalo da tradição ganha um novo sentido. Agora, a arte dos traços, ou seja, a fotografia, não é simplesmente substituída por uma nova arte das sombras. O próprio real é cada vez mais recebido como sombra. A vertigem barroca é ainda mais radicalizada.

Este trabalho de aproximação do espectro, de mergulho na sombra, também pode ser vislumbrado na série Enigmas, do início dos anos 1980, primeira vez que as sombras aparecem de modo enfático na obra da artista. Nela, objetos do cotidiano são apresentados sob a sombra de outros objetos, não menos banais. Mas, novamente, trata-se de sombras sem referentes, traços sem origem. Com isso, Silveira enfatiza o paradoxo - e também as contradições de nossa sociedade -, ao aproximar uma máquina de escrever (trabalho intelectual) e um martelo, ou um pente (ligado à esfera íntima, do cuidado de nossa aparência) com uma panela de

23. "Die Spur ist Erscheinung einer Nähe, so fern das sein mag, was sie hinterließ. Die Aura ist Erscheinung einer Ferne, so nah das sein mag, was sie hervorruft." ("O traço é a aparição de uma proximidade, por mais longe que esteja, o que o deixou. A aura é a aparição de uma distância, por mais próximo que esteja, o que a evocou."). BENJAMIN. Das Passagen-Werk, p. 560 
pressão. Nas séries Eclipses e Desaparências, dos anos 1990 e 2000, encontramos o mesmo procedimento de estranhamento, reafirmando o projeto de descolamento entre os traços e seu referente. Já na série Dilatáveis, feita ainda sob a ditadura e com o mesmo jogo de sombras em seu centro, vemos também como atua, na poética de Silveira, uma sutil, mas não menos virulenta, crítica ao poder. As distorções e dilatações das imagens correspondem a uma tradução do espaço cultural e midiático de figuras ícones daquele período. O dispositivo de inscrição revela o inconsciente de uma época, no caso, um universo forjado a ferro e fogo pela violência. Na obra confluem a crítica da representação (estética) e a crítica da (não)representação (política). E, com isso, a artista dá um novo sentido à tradicional representação do jogo de sombras longas.

Derivadas de uma pequena fonte de luz, estas sombras já haviam sido exploradas por da Vinci em seus desenhos ${ }^{24}$ e, sobretudo no barroco, como vemos na prancha muito reproduzida de Samuel van Hoogstraten e nas máquinas de projeção de sombra, a Laterna Mágica e a Máquina Parastática, de Athanasius Kirchner. Porém, nota-se que a sobreposição entre o estético e o político em Silveira é apenas mais evidenciada por esta série, já que seu olhar político é uma constante. O mesmo também se dá, por exemplo, em outras obras, como o genial Pudim arte brasileira (1977), o To be Continued... (Latin american Puzzle), de 1998, uma saborosa ironia da imagerie latino-americana, de seus tipose estereótipos, bem como em Encuentro, de 1991. Nesta última, as sombras parecem revelar o caráter dos personagens do encuentro. Como sabemos, na tradição da skiagraphia, a phisiognomia de Lavater desempenhou um papel fundamental. Esse pastor suíço tentou fazer da arte da cópia dos perfis um desdobramento da confissão. ${ }^{25}$ Para ele, sua máquina de desenhar silhuetas permitiria mergulhar na verdade oculta das pessoas via revelação da sua sombra. Silveira ironiza esta tradição fisiognômica, interpretando a seu modo esta arte de ler sombras. Para tanto, provavelmente tenha sido inspirada por cartunistas como Grandville, que no século XIX, já fazia este jogo pseudofisiognômico com as sombras. Em Silveira, vemos, portanto, também o encontro de uma tradição irônica e cômica com aquela dita séria da representação. Também no barroco, com suas anamorfoses e com seu Trauerspiel, como bem mostrou Walter Benjamin, a desconstrução da representação acompanhava uma crítica do poder não menos radical.

24. STOICHITA. Breve bistoire de l'ombre, p. 67.

25. STOICHITA. Breve histoire de l'ombre, p. 175. 
O mesmo gênero de crítica via encenação de um jogo de sombras se dá no impactante The saint's paradox, de 1994. Como Regina Silveira nos conta, aqui sobrepôs duas imagens de poderosos com suas dimensões desproporcionais. A imagem que simula originar a sombra enorme é um pequeno santo de madeira, "uma escultura popular da Guatemala" que "representa Santiago Apostolo". Já a sombra é "uma distorção da silhueta do monumento equestre ao patrono militar brasileiro, feita pelo modernista Bracheret, nos anos 1940 e situado em praça pública, no centro de São Paulo". ${ }^{26}$ Silveira nos conta que "ao aproximar trans-histórica e paradoxalmente as duas figuras quis comentar as recorrentes e sempre renovadas relações entre poder, militarismo e religião na América Latina." ${ }^{27}$ Ou seja, seu gesto de colecionar e sobrepor imagens do poder distante no tempo e no espaço, revela uma visão da história diacrônica e arruinada, que, benjaminianamente, a vê como uma repetição e reiteração do poder violento. $O$ espectro de Duque de Caxias se casa aqui com a imagem de um não menos violento Santiago Matamoros, "invocado secularmente na expulsão dos árabes da Península Ibérica e patrono da América espanhola, também invocado nas guerras coloniais que dizimaram populações indígenas e suas culturas". ${ }^{28}$ Duque de Caxias, como sombra aumentada do militar espanhol, seu antecessor, não deixa de iluminar a história do continente americano. Nesse sentido, também é digno de nota a obra De artificiali perspectiva 3, de 1976. Já o título aponta para a confluência entre teoria da representação pictórica e política. O latim, nos títulos de Silveira, citam ironicamente a tradição acadêmica e a grande representação no seu modelo clássico, e ao mesmo tempo - ironicamente - permitem um trânsito entre as línguas na nossa era globalizada. Os "pontos de fuga" de De artificiali perspectiva 3 são projetados sobre senhores indiferentes à cena. O paradoxo também rege esta obra.

Já na série Desaparecências, reencontramos o cavalete e o estúdio de artista. Aqui tudo se torna sombra e virtualidade. O cavalete e o estúdio outros elementos da representação clássica - são também espectros em uma era dominada por novas mídias que deglutem o velho atelier. A linha pontuada, como notou Angélica de Moraes no texto "Vestigios de una ausencia", "costuma indicar a parte invisível do sólido representado." O estúdio e o cavalete "desaparecidos"

26. Entrevista cedida pela artista.

27. SILVEIRA. Linha de sombra.

28. Entrevista cedida pela artista.

29. SILVEIRA. Linha de sombra, p. 42. 
literalizam o novo momento das artes. Em Eclipses, vemos emergir os óculos com sua sombra distorcida, imagem que vem de Anamorfas, de 1980. De certo modo, em Anamorfas já assistimos a um anúncio da poética das sombras que se desenvolve a partir de Enigmas.

Estas voltas autorreferentes na obra de Silveira, típicas da arte contemporânea, ganham um novo sentido, se nos lembrarmos de sua obra-citação de Duchamp, já comentada. Como outro artista, Andy Wahrol, que não só se autocitava, mas também trabalhava com a serialização como meio de desconstrução da representação e de elaboração da hiperinflação de imagens, Silveira reinveste de sentido o ato de repetir. Já o gancho de rede que na sua sombra projeta um revólver pode ser lido como uma revelação do nosso "inconsciente ótico", apropriando-nos dessa expressão de Benjamin. Mas esse revólver também é uma citação de vários outros revólveres nas obras da artista, como em A arte de desenhar (1982), Encuentro (1991) e Inside/Out (Gun) (1996). De resto, ao colocar o revólver entre as suas figuras de eleição, Silveira está literalizando o que o crítico Walter Benjamin falou de algumas obras das vanguardas: elas haviam se transformado em um tiro. ${ }^{30}$ Mas esta leitura não pode perder de vista a ironia da artista, que, com seu gesto de dar sombra ao que não tem corpo, também nos faz rir com seus títulos ready made, como em Bigode (Série Colgantes), de 2008. Este bigode-sombra pode, por sua vez, ser outra citação, de outro traço negro e iconoclasta, a saber, o famoso bigode que Duchamp pintou sobre a Mona Lisa de Da Vinci, o seu "L.H.O.O.Q".

Por último, nestes comentários das obras de Silveira calcadas na projeção de sombras, lembro de "Transitório/Durevole" (trabalho feito em colaboração com

30. "Ao recolbimento [Versenkung], que se transformou, na fase da degenerescência da burguesia, numa escola de comportamento anti-social, opõe-se a distração [Ablenkung], como uma variedade do comportamento social. O comportamento social provocado pelo dadaísmo foi o escândalo. $\mathrm{Na}$ realidade, as manifestações dadaístas asseguravam uma distração intensa, transformando a obra de arte no centro de um escândalo. Essa obra de arte tinha que satisfazer uma exigência básica: suscitar a indignação pública. De espetáculo atraente para o olhar e sedutor para o ouvido, a obra convertiase num tiro. Atingia, pela agressão, o espectador. E com isso esteve a ponto de recuperar para o presente a qualidade tátil, a mais indispensável para a arte nas grandes épocas de reconstrução histórica. O dadaísmo colocou de novo em circulação a fórmula básica da percepção onírica, que descreve ao mesmo tempo o lado tátil da percepção artística: tudo o que é percebido e tem caráter sensível é algo que nos atinge." BENJAMIN. A obra de arte na era de sua reprodutibilidade técnica, p. 191s. 
Mirella Bentivoglio), de 1998, o qual chama a atenção porque a temática parece destoar da poética de suas obras em sombra. Mas o título, novamente, ready made, lança uma luz sobre o trabalho. Ao misturar línguas e aproximá-las na mesma medida em que aproxima palavras opostas para formar seu oxímoro, o durável e o transitório, o paradoxo da sombra sem corpo parece ganhar sentido. Dessa vez, a sombra da conhecida artista italiana Mirella Bentivoglio narra um ato também tradicional, a leitura de um livro. A concentração e a solidão formam um todo coeso e apontam para uma era na qual a tradição ainda era não só arquivável em livros, como também recebida de modo sério. Mas este passado se transformou em mera sombra. Portanto, o que se queria durável, o arquivo, é revelado como transitório: e o mesmo valendo para a vida da leitora e, por tabela, para a da(s) artista(s). Se Dibutades e sua filha criaram com seus gestos um meio de arrancar de seu espaço-tempo um presente que foi congelado, permitindo arrastá-lo para outros cronotopoi, originando o paradoxo da representação de um modo geral, que se apresenta como o durável, no caso desta sombra de Silveira, nada mais garante a imortalidade. Ela congela a sombra, não um eventual emissor da mesma.

Assim, trata-se de uma reflexão sobre o ser efêmero das suas apresentações/instalações e da arte de um modo geral na era do virtual. Como nas alegorias barrocas (e também em muitos dos tromp l'oeuil, a exemplo do famoso The Ambassadors, de Hans Holbein) também aqui estamos diante de um memento mori. A sombra vale como uma recordação da casa dos mortos. O fato de a maior parte desta sombra estar sendo projetada em uma parede vertical é não só uma alusão aos quadros da história da arte, mas à sua própria origem, ou seja, ao mito de Dibutades. Mas nessa nova cena da origem das artes não existe original, nostalgia ou erotismo. Ao invés do pai, Dibutades, que transformaria a silhueta em escultura, temos a fotografia, que propaga um espectro. A fotografia fixa esta sombra solitária que é apresentada em galerias e museus. Ela fixa e a transporta para dentro da Internet, de catálogos e de Power Points. A fotografia também é paradoxal, ela também rasga um determinado cronotopo e permite que, como o diabinho da novela de Chamisso o fez com a sombra de Schlemihl, nós dobremos o cronotopo e o guardemos no "bolso". Mas esta fixação da fotografia é tudo menos uma garantia de eternidade. $\mathrm{E}$ isto vale ainda mais na era das imagens digitais. A série Dobras, de final dos anos 1990, apresenta formas em sombra tridimensionais. Via pequenas dobras, Regina Silveira dá volume aos seus objetos de sombra. Ela aqui literaliza o gesto de Schlemihl de dobrar sombras. Assim realiza mais um passo, decisivo, no sentido do seu projeto de retirar a sombra de sua posição secundária 
e recalcada. É quase como se esta série representasse o final de uma etapa, a "fase das sombras", e liberasse a artista para novos projetos. O volume passou a ser a partir daqui uma presença cada vez mais evidente em suas obras. No plano temporal, o volume é o correlato da temporalidade. Dar volume às sombras significa também narrá-las, processá-las no sentido de uma elaboração.

Dessa poética do índice surgem também na obra de Silveira uma série de trabalhos que apresentam rastros e pegadas. Tropel (1998) ocupou a fachada da Bienal de São Paulo com centenas de pegadas de animais de várias espécies. Novamente encontramos traços, mas aqui de modo talvez menos paradoxal que nas sombras sem referentes ou que anamorfoseiam seus objetos. Afinal, o rastro e a pegada possuem sempre uma relação causal com o ser que os originou, mas, ao mesmo tempo, marcam a ausência daquele mesmo que estava na sua origem. A decalagem temporal lhes é intrínseca. Por outro lado, de modo algum estamos longe do paradoxo nessas obras, uma vez que vemos nelas enxames de pegadas ou de marcas de pneus nos lugares mais inusitados. E mais, essas pegadas e marcas se misturam muitas vezes a imagens monocromáticas, quase sempre negras, como a sombra de animais e insetos. Na exposição "Mundus admirabilis e outras pragas", ${ }^{31}$ de 2008, vemos variações sobre o tema das pragas bíblicas. Essa invasão de animais asquerosos, como sapos e insetos gigantes, que ocupam o espaço arquitetônico, a toalha de mesa e a louça, são também um convite para a leitura alegórica. Como em Kafka ou em Clarice Lispector, Silveira nos faz ver o lado sombrio e abjeto daquilo que nos parece banal e inocente, a exemplo da porcelana branca onde comemos. Na exposição dessa série em Brasília, conforme se notou, a alusão à corrupção era clara, como aponta o próprio título de uma das obras: Corruptio. Não se pode descartar aqui uma alusão ao romance distópico clássico de Aldous Huxley, publicado em português com o título Admirável mundo novo. Em "Irruption Series (Saga)", de 2006, uma mostra em Taipei, vemos pegadas humanas em torno das entradas do salão de exposição da Bienal.

Como abordaremos, esta atração pelos umbrais - uma marca de Silveira e de Benjamin - tem um papel fundamental em sua obra. Mas essa ocupação de amplas áreas arquitetônicas também desdobra outros momentos do projeto de Silveira, como seus labirintos, dos anos 1970. Se nos anos 1970 a cidade era apropriada via serigrafia, projetando-se labirintos na selva de pedra, onde os compartimentos às vezes parecem gavetas representando os locais em que a

31. SILVEIRA. Regina Silveira: mundus admirabilis e outras pragas. 
nova classe média teria que sobreviver, já nas obras com pegadas e rastros trata-se de uma apropriação muito mais concreta de amplos espaços. Aqui se dá com muita força a conhecida e original confluência da obra de Silveira com a arquitetura e a cidade. Esse encontro também reafirma a ideia de que a recepção da obra contemporânea ocorre cada vez mais em espaços dispersivos e de forma corpórea e distraída. Locomovendo-nos, na imersão, penetramos e, para falar com Benjamin, "tateamos" a sua obra. As Derrapagens, da segunda metade dos anos 2000, acrescentam a esta cena a incorporação de marcas de pneu que lembram a violência de nossas ruas.

Se é verdade que existe algo de belo nesta apropriação das derrapagens e na sua verticalização, não deixa de ser verdade também que assistimos a uma apropriação poética dos choques da vida urbana. Regina Silveira, ainda uma vez, desloca e ressignifica estas derrapagens ao decorarmuseus, lojas e galerias com elas. As ruas sobem as paredes desestabilizando nossos passos e abrindo o espectador/passante a novas experiências. Da mesma forma como em Enigmae em Mundus admirabilis, com as suas impressões e projeções sobre louças, toalhas de mesa e espaços de exposição, aqui também, nas Derrapagens, vemos o mundo sendo, aos poucos, todo conquistado para o espaço estético que antes era limitado à tela e depois ao papel fotográfico. Se tudo é suporte, é porque, para Silveira, os limites da arte e do político devem ser a toda hora postos em xeque. O abalo da reprodutibilidade, ampliado na era da síntese de imagens, também implica esta constante revisão dos limites da arte. A imaginação pede passagem.

Por último, tratemos da luz. Na obra de Silveira, é muito interessante observar como ela foi transitando, na virada do milênio, de um predomínio da sombra para um jogo cada vez mais luminar. O que lhe importa é o jogo entre estas duas esferas, ou entre os dois lados da esfera: o iluminado e o sombrio. Afinal, como vimos, lumen et umbrae é o termo latino que traduzia o grego skiagraphia e se Silveira faz de sua escrita de sombras uma escrita de luz, literalizando a foto-grafia, é porque ela sabe que uma escritura é o negativo da outra e ambas estão sempre juntas. Assim, na sua Solombra, ainda de 1990, vemos já neste título da obra a fusão das duas esferas. Feita com carpete e holofote, apresentada no SESC Pompéia de São Paulo, é um evidente jogo irônico com a tradição da perspectiva que é fundida a um conceito de arte site specific. Ao invés do universal, ou seja, da redução matemática do real ao espaço de representação da tela, vemos o próprio espaço de exposição ser transformado em um jogo de sombra e luz irredutível. 
Já em Lâmpada, de 1995 e em Quimera, dos anos 2000, nos deparamos novamente com um estudo paradoxal sobre a relação entre luz e sombra. De uma lâmpada acesa emana a sombra. Se existe uma lógica aí, afinal, a sombra é um fruto da luz, o paradoxo está em estabelecer uma continuidade onde deveria haver interrupção. Esta continuidade aparece também em Descendo a escada, de 2004, um tromp l'oeuil feito em videoprojeção que recria neste meio uma obra de Silveira antes feita em pintura sobre recorte de poliestireno, o Escada inexplicável, de 1999. Essa escada é uma pura projeção, sombra luminosa, jogo, portanto, entre luzes e sombras em um espaço tridimensional, que resulta na ilusão de que estamos de fato contemplando o poço de um prédio rodeado por suas escadas. Esse buraco virtual faz parte do projeto de estetizar o espaço público e, nessa proposta, o dispositivo do projetor é muito bem explorado.

A projeção tem sua origem, como na caverna de Platão e no mito de Dibutades, na luz originária. É esta fonte primária (a luz primária que vimos acima) que garante o jogo da perspectiva. Silveira recria e brinca com as lições clássicas de perspectiva, de modo didático e monumental, para desconstruí-las. A luz projetada não é nem um falso jogo de sombras (como avesso da verdade das ideias luminosas), nem está na origem de uma obra "eterna". Antes, a obra é site specific, efêmera e sua duração depende da fotografia, um meio que encena a permanência no tempo, mas que também representa o processo de apagamento da memória.

Tanto em Equinócio como em A lição, ambas de 2002, bem como em Duplo, de 2003, reencontramos esse trabalho de desconstrução da era e modos de representações. Equinócio é o momento de perfeita divisão da Terra entre a luz e a sombra. Mas Silveira reverte esta situação ou a torna paradoxal, ao colocar diante do espectador duas esferas iluminadas do mesmo lado. A metade sombria, que deveria estar voltada ao espectador, está postada para a fonte de luz, uma rosácea. Como em Magritte, que punha em um mesmo espaço, lado a lado, a noite e o dia, ou, em Chirico, com suas citações da arquitetura clássica e do jogo de sombras da grande era da perspectiva, as obras de Silveira também geram um enigma e ironizam a tradição.

Porém, diferentemente do que se passa no surrealismo, o registro de Silveira não é só o da ironia e da desconstrução. Ao expandir sua obra por meio de uma arqueologia das sombras, e ao invadir os espaços arquitetônicos e a cidade, ela leva a lição das vanguardas a novas conjunções, um aspecto que os vanguardistas históricos não haviam vislumbrado. Mesmo porque, obviamente, eles viveram em época bem diversa, em termos culturais, sociais e tecnológicos. Em A lição, como 
lemos no catálogo do CCBB do Rio que apresentei acima, a artista retoma as formas que Cézanne apresentara como partes essenciais do estudo do pintor: "Deve-se antes de tudo estudar as formas geométricas: o cone, o cubo, o cilindro, a esfera. Quando alguém sabe representar essas coisas em sua forma e em seus planos, necessariamente sabe como pintar." ${ }^{32}$

Mas Silveira congela as sombras, tal qual a filha de Dibutades, contudo sem dar o passo seguinte. Assim, ela transforma a lição em paradoxo. Não existe mais o ponto de vista e sua interação com a fonte de luz e o ponto de fuga. Ao congelar a sombra e a luz, desmonta o dispositivo da Paideia artística, retirando também o homem renascentista de cima de sua torre de marfim. Não existe mais a afirmação do indivíduo e de seu ponto de vista único. Essas projeções, que aparecem nessas obras ainda como citações da tradição clássica, são aplicadas de modo bem distinto em obras como Transit, de 2001, e em Super herói (Night and Day), de 1997, e em Passeio selvagem, 2009. Aqui, reencontramos a tradição barroca da lanterna mágica e o trabalho com a arqueologia do cinema - um tema que também fascinava Benjamin e se tornou fundamental na era das imagens digitais. Novamente, também a cidade se torna o palco das criações de Silveira, rompendo com os muros das galerias e museus e chamando um público maior para a recepção de sua obra. Ao projetar super-heróis, ufos, pegadas de insetos gigantes, a artista expõe tanto imagens de desejo, forjadas ao longo do século XX, ou seja, toda uma série de super-heróis redentores, como também brinca com a estética do sublime e do medo, explorando aquilo que Freud detectara tão bem em seu Totem e tabu: os demônios nada mais são do que projeções de medos normalmente não conscientes. ${ }^{33}$ Assim, os insetos expressam sentimentos ligados ao amorfo e ao abjeto, são expressões daquilo que está na origem da cultura, na medida em que remetem a recalcamentos originários. São o avesso e a negação do simbólico. Já os super-heróis seriam uma reversão dessa angústia: expressão do desejo de redenção. Essas imagens de super-heróis se tornaram parte da cultura moderna, da indústria cultural e, desde o pop, foram incorporadas ao "alto" circuito das artes. Mas aqui, novamente, sombras e luzes interagem na coreografia de sua obra.

Essa mesma expansão da ideia de obra pode ser vista em outra criação da artista que trabalha um paradoxo: Entrecéu, de 2007, na qual vemos o céu projetado no chão e na parede de uma galeria, assim como em Mil e um dias,

32. SILVEIRA. Luz e sombra, p. 18.

33. FREUD. Totem und Tabu, p. 353. 
do mesmo ano, na qual se projeta, sobre uma porta, a sucessão de dias e de noites. Essa obra também tem um som de fundo, com "vozes de crianças e barulhos noturnos diversos, que são outros vestígios do tempo, vindos da minha memória", conta-nos a própria artista. É como se a projeção permitisse perfurar a porta e transportar o espectador para outro lugar. A porta fechada é "aberta" pela projeção, torna-se tela. Não no sentido de um souvenir-ecran (Deckerinnerung, ou seja, memória encobridora), mas sim como local de manifestação de traços de memória e de imagens de desejo, que podem "arrombar" a concretude da porta. O céu azul que se vê, será depois reencontrado nas paredes do MASP, em 2010. Nesse museu, pudemos ver mais uma dessas obras que ocupam grandes espaços arquitetônicos. Nas paredes de vidro do prédio de Lina Bo Bardi, foi aplicado vinil simulando um bordado de ponto cruz, representando o céu azul claro, límpido, com nuvens brancas - paisagem praticamente inexistente em São Paulo, em virtude da poluição da cidade, ou seja, trata-se novamente de um verdadeiro paradoxo. Regina Silveira, ao fazer essa intervenção gigante nas paredes do MASP, como o artista búlgaro Christo fizera com o Reichstag (em 1995), ressignifica esse prédio e a própria Avenida Paulista, um símbolo de São Paulo.

Vários outros trabalhos anteriores da artista convergem para esta grande obra, de suas Destruturas urbanas (1976) ao Embroidery (2003), que também simulava o bordado. O enorme prédio do MASP surge como um pedaço de céu que desceu à terra: o prédio de concreto fica leve como um balão de gás e parece que será levado pela mais fraca brisa. Esse céu congelado instalado no MASP provoca o citadino, pois é tanto lembrança de algo que não mais existe na cidade, ou seja, um plácido céu azul, como também do tempo mais lento e apaziguador, aquele ligado à arte manual de bordar. O azul, em sua inocência anil, parece um paradoxo ou uma utopia. O bordado, trabalho associado culturalmente ao sexo feminino, ressignifica a trama da cidade: falocêntrica e poluída. O fato de ser o vinil o meio utilizado pra essa simulação de idílio, só torna a obra mais irônica, um traço comum em Silveira. Esta obra, assim como o Memoriazul, de 2005, que consistia na aplicação de vinil também azul no Palácio de Cristal, no Parque Retiro em Madrid, na exposição Lumen (2005), fazem renascer uma ampla área arquitetônica e urbana.

Silveira denominou esta sua obra de Madrid, ao lado da obra Lumen (da exposição Claraluz), de 2003, apresentada no CCBB-SP, como obras "catastróficas" que congelam e encenam uma narrativa do desastre. A obra Lumen,

34. Entrevista cedida pela artista. 
do CCBB-SP, projeta fragmentos de clarabóia do prédio, criando uma arquitetura caótica no espaço interno dessa ex-agência bancária. Como a artista nos explica em seu site: "A operação principal no vão central do edifício é a desconstrução da imagem da clarabóia, ou seja, seu estilhaçamento e recomposição como imagem luminosa de grande formato a ser projetada sobre as paredes e tetos dos diversos andares." ${ }^{35}$

Esta colagem arquitetônica provoca uma desterritorialização. Sem contar o efeito de vertigem e de virtualização do concreto, algo que não deixa de recordar a arquitetura imaginária dos Cárceres de Piranesi, do século XVIII. Tanto Piranesi quanto Silveira trabalham com a arquitetura e sua recriação via o potencial de virtualização característico das artes. A temática sombria dos dois trabalhos também permite aproximá-los, por mais distantes que sejam suas poéticas. Para tocar em uma das diferenças mais evidentes, Silveira cria este "ser sombrio" com uma projeção luminosa. Em Madrid, também simulou a ruptura dos vidros da clarabóia. ${ }^{36}$ Esta catástrofe encenada reativa a vertente sublime da obra e podemos falar de um verdadeiro sublime arquitetônico e urbano que ronda as criações atuais da artista. Estas imagens congeladas da catástrofe transformam a tragédia em um jogo autorreflexivo: Trauerspiel, falaríamos, inspirados por Benjamin. Lutilúdio, na tradução deste termo feita por Haroldo de Campos. Não por acaso, esta narrativa da catástrofe tem por título Memoriazul: a ideia é a de criar uma "foto-grafia" azul da catástrofe. Uma memória na qual céu e terra se confundem. Mas, o azul celeste dá um tom de paz sublime a esta encenação do esfacelamento.

Vale lembrar que também Entrecéu, no Museu do Vale do Rio Doce, representava uma catástrofe, uma invasão do céu na estrutura sólida do museu. Essas reviravoltas, ou seja, literalmente, catástrofes (viradas para baixo), trazem o céu para terra e revertem os clássicos tromp l'oeuil que projetavam céus virtuais nos tetos das igrejas. Silveira trabalha como um Michelangelo voltado para as forças telúricas, e não para os deuses do céu. Ela cria uma arte que reveste sua atividade de novo sentido. Se sua obra é quase toda indicial, nos últimos anos enfatiza projetos de expansão do campo artístico, onde os umbrais - entre o estético e o político, o dentro e o fora, o claro e o escuro - são a todo momento retraçados. Citemos a artista:

35. SILVEIRA. Lumen, 2002. Disponível em: <http://reginasilveira.uol. com.br/claraluz.php\#>. Acesso em: 17 abr. 2011.

36. Entrevista cedida pela artista. 
Desde minha primeira intervenção direta sobre a arquitetura (Simile, 1988, no antigo Centro Galileo, de Madrid) tenho me concentrado na natureza ambígua e misteriosa dos umbrais. Janelas, portas e arcadas são passagens entre o dentro e o fora dos espaços construídos, que funcionam como aberturas ou epidermes finas por onde eles fisicamente se conectam e deixam passar a luz, o vento e - mais metaforicamente - também a sombra. Muitas vezes inverti esta relação, usando os umbrais para criar estranhamentos ou projeções de sombra totalmente fora de lugar. Sempre pude imaginar os umbrais como lugares para acontecimentos improváveis e extraordinários, além de aberturas para o território do fantástico de onde podem provir invasões e irrupções de todo o tipo. Eles são também espaços de fluxo e nesta condição podem aludir igualmente ao tempo e à memória. ${ }^{37}$

Esta confluência entre uma estética da encenação da catástrofe e essa concepção dos umbrais como espaços assombrados e de experimento de inversões, reversões e entrada do novo, mais uma vez afirma a originalidade da obra de Regina Silveira na cena artística contemporânea. Ela consegue fazer convergir em seus trabalhos, como vimos, não só a história da arte como representação (do Renascimento ao século XVIII) e da construção do homem romântico, que leva sua sombra dentro de si e se relaciona com ela como seu duplo, mas também essa complexa poética dos umbrais. Então, percebemos de modo mais evidente uma manifestação do mítico e do místico na obra de Silveira, que à primeira vista parece totalmente embebida do profano. O umbral, como lemos em Benjamin, é o local de anúncio do inteiramente outro. Numa visão do tempo como saturado de "agoras" - ou seja, o oposto do tempo homogêneo e vazio - ele percebia que "cada segundo era a porta estreita pela qual pode entrar o Messias". ${ }^{38}$ Além disso, a soleira é o local de passagem entre o mito e a razão, entre o sagrado e o profano, entre o sonho e a vigília, entre a sombra e a luz, em suma, entre a vida e a morte. Cassirer, na sua obra sobre o pensamento mítico, lembra que na Roma antiga Terminus era um deus e "um sentimento originário, mítico-religioso, conecta-se ao evento do "umbral' espacial". 39

37. Entrevista cedida pela artista.

38. Benjamin. Sobre o conceito da história, p. 232.

39. CASSIRER apud MENNINGHAUS. Schwellenkunde. Walter Benjamins Passage des Mythos, p. 28. 
O projeto de Silveira de realizar uma arqueologia da representação, calcada em um trabalho com as sombras e os rastros, levou-a em direção a uma nova etapa onde cada vez mais o espaço com seus umbrais e a luz se fazem presentes. Luz Zul, o nome em palíndromo de uma exposição de 2006, que une também a luz e o azul celeste em uma escritura de luz, foto-grafia, deixa igualmente claro como Silveira agora reinventa as artes. ${ }^{40}$ A exemplo da recente mostra Glossário, o umbral se transforma em local de porosidade entre o campo estético e o espaço público, polinizando a vida com novas experiências.

A luz que se trata aqui não é mais aquela que se queria divina, como em Platão, ou que permitiria a reprodução mimética, como no dispositivo de Dibutades. Essa luz é simples inscrição no espaço. É arte após o ocaso da representação e da era de sua desconstrução, realizada pelas vanguardas e pós-vanguardas. Esta característica escritural dessa nova arte de Regina Silveira (que narra catástrofes, mas que também se abre para o novo) está sintetizada em uma pequena e quase simplória obra de 2001/2003. Refiro-me ao seu Pulsar. uma caixa de fósforos Fiat-Lux possui dentro de si uma fonte luminosa que projeta sua luz em um pequeno espelho. Esse, por sua vez, lança na parede uma luz em forma estrelar. A luz da estrela que vemos é, portanto, reflexo de um reflexo. A sua forma estrelar é fruto de um recorte em uma pequena caixa de fósforos. Trata-se de um jogo de luz e sombra, mas que não está mais sob a sombra da representação ou mesmo da ausência. A arte agora percebeu que também pode ser isso: Fiat Lux.

Shadows and Lights: Technical Reproduction, the Ephemeral Traces of Disappearance and the "Pure T" in the Work of Regina Silveira

Abstract: The text analyses the shadow and light poetics in the works of the artist Regina Silveira. It shows its connections with the old tradition of skiagraphia as well as with the history of the reflections and theories about the shadow. The article presents how Silveira's shadow's writing, that in the beginning pointed towards something absent and verdrängt (repressed), takes the shape of a light writing, "pure trace", without the anguish of the absence. Keywords: skiagraphia, shadow, light writing.

40. SILVEIRA. Luz Zul. 


\section{Referências}

BENJAMIN, Walter. Das Passagen-Werk. In: Gesammelte Schriften. Frankfurt am Main: Suhrkamp, 1983. v. 5

BENJAMIN, Walter. A obra de arte na era de sua reprodutibilidade técnica. In: . Magia e técnica, arte e política. Tradução de Sérgio Paulo Rouanet. São Paulo: Brasiliense, 1985

BENJAMIN, Walter. Sobre o conceito da história. In: Magia e técnica, arte e política. Tradução de Sérgio Paulo Rouanet. São Paulo: Brasiliense, 1985.

FREUD, Sigmund. Totem und Tabu. Studienausgabe, Frankfurt am Main: Band 9, p. 287-444, 1974.

KEULS, Eva C. Plato and Greek Pinting. Leiden: Brill, 1978.

LOCKE, John. Essay Concerning the Human Understanding. Cambridge University Press, 2007.

MENNINGHAUS, Winfried. Schwellenkunde. Walter Benjamins Passage des Mythos. Frankfurt am Main: Suhrkamp, 1986.

PLINY. Natural History. Books 33-35. Translated by H. Rackham. Cambridge: Harvard University Press, 1999.

PLATÃO. A república (Da Justiça). Tradução de Edson Bini. Bauru: EDIPRO, 2006.

SCHWARZ, Arturo. The Complete Works of Marcel Duchamp. Revised and expanded Paperback Edition. New York: Delano Greenidge Editions, 2000. v. 1.

SELIGMANN-SILVA, Márcio. O local da diferença. Ensaios sobre memória, arte, literatura e tradução. São Paulo: Editora 34, 2005.

SILVEIRA, Regina. Linha de sombra. Curadores José Roca e Alejandro Martin. Rio de Janeiro: 12 out. 2009 - 3 jan. 2010. Centro Cultural Banco do Brasil.

SILVEIRA, Regina. Luz Zul. Curador Marcio Doctors. Rio de Janeiro: 2006, Instituto Telemar.

SILVEIRA, Regina. Regina Silveira: mundus admirabilis e outras pragas. São Paulo: 08 out. - 29 nov. 2008, Galeria Brito Cimino.

SILVEIRA, Regina. Site pessoal da artista. Disponível em: $<$ http://reginasilveira. uol.com.br>. Acesso em: 17 abr. 2011.

STOICHITA, Victor I. Breve histoire de l'ombre. Genève: Droz, 2000. 